\title{
Biodisel dari Mangrove Jenis Nyamplung (Callophylum inophyllum) sebagai Alternatif Pengganti Bahan Bakar Minyak Fosil
}

\author{
Suyono ${ }^{1}$, Ninik Umi Hartanti ${ }^{1}$, Agus Wibowo ${ }^{2}$, Narto ${ }^{1}$ \\ ${ }^{1}$ PS Budidaya Perairan, Fak. Perikanan dan IImu Kelautan Universitas Pancasakti Tegal \\ ${ }^{2}$ PS Teknik Mesin, Fak. Teknik, Universitas Pancasakti Tegal \\ Email : suyono.faperi. ups@gmail.com
}

\begin{abstract}
Resources of fossil fuel continue to decrease and cannot be renewed so that replacement alternative is needed. Biofuels (biodiesel) become one of the alternatives because it can be renewed and environmentally friendly. Firstgeneration biodiesel from food sources and second generation of food waste can disrupt the availability of food. Those are inefficient because it requires extensive land for its provider. Seed of nyamplung (Callophylum inophyllum) is very potential as biodiesel raw material because of its oil content $40-70 \%$ is high compared to other types of plants, such as jatropha range of $40-60 \%$ and palm of $46-54 \%$, raw materials saving and having twice of fuel as much as kerosene. The general purpose of this research is to produce third generation biodiesel from nyamplung as material to overcome fossil fuel crisis especially for fishermen and farmers in coastal area of Brebes Regency and surrounding areas. To be able to achieve the goal / general target is done by assessing oil content in nyamplung seed, biodiesel synthesis, intensive culture techniques and models of development of mass culture. The biodiesel yield produced from nyamplung seed oil in this study was $82.87 \%$, in the range of biodiesel yields of previous researchers through a single stage transesterification of $79.03-91,00 \%$. Cetana number and alkyl ester figures in the resulting biodiesel respectively 79.5 and $99.71 \%$ have met the Indonesian National Standard (SNI). The resulting density was $893.1 \mathrm{~kg} / \mathrm{m} 3$, fog point was $20^{\circ} \mathrm{C}$ and total glycerol was $0.26 \%$, was approaching the SNI by an insignificant difference, while the acid number generated was $1.86 \mathrm{mg} \mathrm{KOH} / \mathrm{gr}$ of biodiesel and the biodiesel viscosity was $15.7 \mathrm{~mm}^{2} / \mathrm{s}$ has not fulfilled the SNI significantly. To improve the number of acids and viscosity is still needed refinement biodiesel synthesis process through the diversification of the number of esterification stages, alternative types and catalytic levels or optimization of transesterification reaction temperature.
\end{abstract}

Keywords: biodiesel, nyamplung, environmentally friendly

\begin{abstract}
Abstrak
Sumber bahan bakar minyak fosil terus berkurang dan tidak dapat diperbaharui sehingga diperlukan alternatif penggantinya. Bahan bakar nabati (biodisel) adalah salah satu alternatifnya karena dapat diperbaharui dan ramah lingkungan. Biodisel generasi pertama dari sumber makanan dan generasi kedua dari limbah pangan dapat mengganggu ketersediaan bahan pangan dan tidak efisien karena membutuhkan lahan luas untuk pengadaanya. Biji nyamplung (Callophylum inophyllum) sangat potensial sebagai bahan baku biodisel dikarenakan rendemen minyaknya $40-70 \%$ tergolong tinggi dibandingkan jenis tanaman lain, misalnya jarak pagar sebesar $40-60 \%$ dan sawit 46-54\%, hemat bahan baku dan memiliki daya bakar dua kali lipat dibandingkan minyak tanah. Tujuan umum penelitian ini adalah menghasilkan bahan bakar nabati (biodisel) generasi ketiga dari tanaman mangove jenis nyamplung sebagai bahan mengatasi krisis bahan bakar minyak fosil khususnya bagi para nelayan dan petambak di wilayah pesisir Kabupaten Brebes dan sekitanya. Untuk dapat mencapai tujuan/target umum tersebut dilakukan dengan mengkaji kandungan minyak pada biji nyamplung, sintesis biodiselnya serta teknik kultur intensif dan model pengembangan kultur massalnya. Yield biodisel yang dihasilkan dari minyak biji nyamplung pada penelitian ini sebesar $82,87 \%$, berada pada kisaran yield biodisel hasil para peneliti terdahulu melalui transesterifikasi satu tahap sebesar $79,03-91,00 \%$. Angka setana dan alkil ester pada biodisel yang dihasilkan masing-masing sebesar 79,50 dan $99,71 \%$ sudah memenuhi Standar Nasional Indonesia (SNI). Densitas yang dihasilkan sebesar $893,1 \mathrm{~kg} / \mathrm{m}^{3}$, titik kabut $20^{\circ} \mathrm{C}$ dan gliserol total $0,26 \%$ sudah mendekati SNI dengan selisih yang tidak signifikan, sedangkan angka asam yang dihasilkan sebesar $1,86 \mathrm{mg} \mathrm{KOH} / \mathrm{gram}$ biodisel dan viskositas biodiselnya $15,7 \mathrm{~mm}^{2} / \mathrm{s}$ belum memenuhi SNI secara signifikan. Untuk menyempurnakan angka asam dan viskositas tersebut masih diperlukan penyempurnaan proses sintesa biodisel melalui diversifikasi jumlah tahapan esterifikasi, alternatif jenis dan kadar katalisator ataupun optimalisasi suhu reaksi transesterifikasinya.
\end{abstract}

Kata kunci : biodisel, nyamplung, ramah lingkungan

\section{Pendahuluan}

Peningkatan kebutuhan bahan bakar minyak (BBM) selama dekade terakhir ini sebagai dampak dari kenaikan jumlah kendaraan bermotor dan aktivitas industri tidak dapat dihindari. Kenaikan permintaan BBM tersebut tidak sebanding dengan ketersediaan jumlah pasokan bahan bakar fosil di alam sebagai sumberdaya alam tak terbaharukan (unrenewable resources) dan tidak ramah lingkungan yang semakin berkurang ketersediaannya sehingga diperlukan alternatif penggantinya.

Penelitian terkait potensi sumberdaya mangrove di Kabupaten Brebes dan sekitarnya sampai saat ini baru sebatas perannya sebagai pencegah abrasi pesisir dan habitat sumber daya perikanan pantai. Biji tanaman nyamplung (Callophylum inophyllum), salah satu jenis 
mangrove di kawasan pesisir sangat potensial sebagai bahan baku biodisel generasi ketiga untuk mengantisipasi terjadinya krisis bahan bakar minyak/fosil. Rendemen minyak nyamplung 40-70\% tergolong tinggi dibandingkan jenis tanaman lain, misalnya jarak pagar $40-60 \%$ dan sawit $46-54 \%$. Biodisel dari biji nyamplung juga hemat bahan baku dan memiliki daya bakar dua kali lipat dibandingkan minyak tanah (Leksono et al., 2012). Pada sisi lain, potensi tersebut masih belum banyak dikaji secara mendalam, sehingga penelitian ini layak untuk dilakukan.

\section{Urgensi Penelitian}

Cadangan sumber bahan bakar minyak dari fosil yang terus berkurang dan tidak dapat diperbaharui menuntut alternatif penggantinya. Bahan bakar nabati (biodisel) menjadi salah satu alternatifnya. Biodisel dapat diperbaharui karena dibuat dari bahan-bahan yang bisa ditumbuhkan atau dibiakkan (Gavrilescu and Chisti, 2005). Aldina. (2014) menyataka $n$ biodisel generasi pertama diproduksi dari sumber makanan misalnya jagung, ubi, kedelai dan sawit sehingga mengganggu ketersediaan bahan pangan. Biodisel generasi kedua dari limbah pangan/pertanian yang mengandung lignocellulosic seperti kayu, jarak dan rumput. Biodisel ini dapat mengurangi sampah namun tidak efisien karena juga membutuhkan lahan yang relatif luas. Penggunaan biji nyamplung sebagai bahan biodiesel menjadi salah satu alternatif pengganti bahan bakar minyak/fosil. Potensi biji nyamplung sebagai sumber bahan bakar nabati ditunjukkan dengan kandungan lemak per satuan luas produksi bahan bakunya yang jauh lebih tinggi dibandingkan sumber lain sebagaimana disajikan pada Tabel 1.

Tabel 1. Perbandingan produksi biodiesel

\begin{tabular}{lcc}
\hline \multicolumn{1}{c}{ Tanaman } & Produksi minyak (l/ha) & Keterangan \\
\hline Jagung(Corn) & 172 & Bahan pakan pokok \\
Soybean & 446 & Bahan pakan pokok \\
Biji bunga matahari (Canola) & 1190 & Bahan pakan pokok \\
Jarak (Jatropha) & 1892 & Bahan pakan pokok \\
Kelapa (Coconut) & 2689 & Bahan pakan pokok \\
Kelapa sawit(Oil palm) & 5950 & Bahan pakan pokok \\
Mikroalga ( lipid 70\%, in biomass) & 136.900 & Proses produksi sulit \\
Mikroalga (lipid 30\%, in biomass) & 58.700 & Proses produksi sulit \\
Nyamplung (Callophylum inophyllum) & 4.500 .000 & Proses produksi mudah \\
\hline
\end{tabular}

Sumber: Chisti (2007) dan Leksono, et al. (2012)

Kabupaten Brebes memiliki potensi sumberdaya kelautan melimpah. Salah satu potensi yang sangat menjanjikan dapat berperan mengatasi krisis energi adalah mangrove khususnya jenis nyamplung (Callophylum inophyllum). Kajian pemanfaatan biji nyamplung di Kabupaten Brebes untuk menghasilkan biodisel ramah lingkungan belum pernah dilakukan sehingga sangat layak untuk dilaksanakan.

Permasalahan yang akan diselesaikan dalam penelitian ini terdiri dari :

1. Bagaimana kualitas biji nyamplung di pesisir Kabupaten Brebes sebagai bahan baku biodisel ?

2. Bagaimana sintesa biodisel dari biji nyamplung yang efisien sesuai standar SNI ?

Tujuan umum penelitian adalah mengkaji pemanfaatan biji nyamplung menjadi bahan bakar nabati (biodisel) ramah lingkungan untuk mengatasi krisis BBM fosil. Tujuan khusus penelitian ini adalah mengkaji potensi biji nyamplung sebagai bahan biodisel serta metode sintesa biodisel biji nyamplung sesuai standar SNI.

Hasil penelitian ini secara akademis diharapkan dapat menjadi sumbangan keilmuan terutama terkait dengan diversifikasi pemanfaatan produk dari mangrove sebagai bahan bakar ramah lingkungan. Adapun secara praktis rekomendasi hasil penelitian ini diharapkan dapat dijadikan bahan acuan bagi penentu kebijakan pengelolaan sumber daya mangrove di Kabupaten Brebes dan sekitarnya dalam pengembangan pemanfaatan eksistem mangrove sebagai bahan bakar ramah lingkungan.

\section{Metode Penelitian}

Penelitian ini dilaksanakan pada bulan April-Juli 2017. Pengambilan sampel dilakukan di wilayah pesisir Kaliwlingi Kabupaten Brebes. Identifikasi sampel penelitian dilakukan di Laboratorium Terpadu Fakultas Perikanan dan IImu Kelautan Universitas Pancasakti Tegal dan sintesa biodisel dilakukan di Laboratorium Kimia 
Fakultas Teknik, Universitas Diponegoro Semarang.

Analisis kandungan minyak pada biji nyamplung secara aumum ditentukan dengan standar mengacu pada Association of Official Analytical Communities (AOAC) 2003. Prosedur analisis meliputi :

1. Pengukuran crude lipid

2. Pengukuran crude protein

3. Pengukuran kandungan abu

4. Pengukuran kandungan crude fiber (AOAC 2003)

5. Pengukuran kandungan air (AOAC 2003)

6. Pegukuran Nitrogen free extract (NFE)

7. Pengujian mineral

Sintesis biodisel dari biji nyamplung dikembangkan dari metode yang telah dilakukan Sukmana dan Purwanti (2011), dengan tahapan sebagai berikut :

1. Penyortiran biji nyamplung

2. Pengeringan biji nyamplung

3. Pengambilan minyak dari biji nyamplung

4. Degumming

5. Esterfikasi

6. Transesterifikasi

7. Karakteristisasi biodiesel
Kualitas biodisel yang dihasilkan diuji dengan Standar Nasional Indonesia (SNI) dan American Society for Testing and Materials (ASTM) meliputi :

a. Uji viskositas (ASTM D 445-04)

b. Uji densitas (ASTM D 1298)

c. Pengukuran titik nyala (ASTM D 93-02a)

d. Penghitungan bilangan asam

e. Penghitungan angka setana

f. Penghitungan bilangan penyabunan

g. Analisis senyawa penyusun biodiesel (KG-SM)

h. Analisis kadar metil ester (KG)

i. Penghitungan kalor pembakaran (ASTM D 240)

j. Perhitungan kalor secara teoritis

\section{Hasil dan Pembahasan}

Hasil uji laboratorium kandungan mineral biji nyamplung disajikan pada Tabel 2 . Selanjutnya hasil analisis kadar air, kadar abu, lemak, serat kasar, protein biji nyamplung dan angka asam, nilai kalor, angka setana minyak nyamplung, serta bilangan penyabunan, densitas, viskositas, senyawa penyusun biodiesel, kadar metil ester biodisel daribiji nyamplung disajikan pada Tabel 3. Adapun senyawa penyusun biodisel dari biji nyamplung disajikan pada Tabel 4.

Tabel 2. Kandungan mineral biji nyamplung

\begin{tabular}{|c|c|c|c|}
\hline No & Sampel & Komponen & Komposisi (\% berat) \\
\hline \multirow[t]{8}{*}{1} & Biii nyamplung * & Karbon C & 13,47 \\
\hline & & Natrium oksida, Na2O & 0,76 \\
\hline & & Magnesium oksida. $\mathrm{MgO}$ & 6,83 \\
\hline & & Fosfor pentaoksida, P2O5 & 35,07 \\
\hline & & Sulfur, SO3 & 2,63 \\
\hline & & Kalium oksida, K2O & 30,31 \\
\hline & & Kalsium oksida, $\mathrm{CaO}$ & 9,81 \\
\hline & & Tembaga (II) oksida, CuO & 1,13 \\
\hline
\end{tabular}

Keterangan : * sampel dengan diabukan

Tempat uji : Laboratorium Terpadu Universitas Diponegoro, Semarang (2017)

Senyawa-senyawa tersebut diperoleh melalui pengumatan dengan menggunakan alat Scanning Electron Microscope- Energy Difraction $X$-ray (SEM-EDX). Karakter biji nyamplung yang permukaan partikelnya bersifat heterogen pada skala mikrometer atau submikrometer tepat diamati dengan menggunakan SEM-EDX. Dengan SEM-EDX dapat diamati karakteristik bentuk, struktur, serta distribusi pori pada permukaan sampel. Karakterisasi menggunakan SEM dilakukan melalui adsorpsi isotermis gas oleh padatan sampel. Jumlah molekul gas yang diadsorpsi pada permukaan luar sampel sangat sedikit dibandingkan dengan yang diadsoprsi oleh porinya (Prihanto et al., 2013). Hasil analisis SEM-EDX biji nyamplung dengan perbesaran 3000 kali disajikan pada rangkaian Gambar 1. 


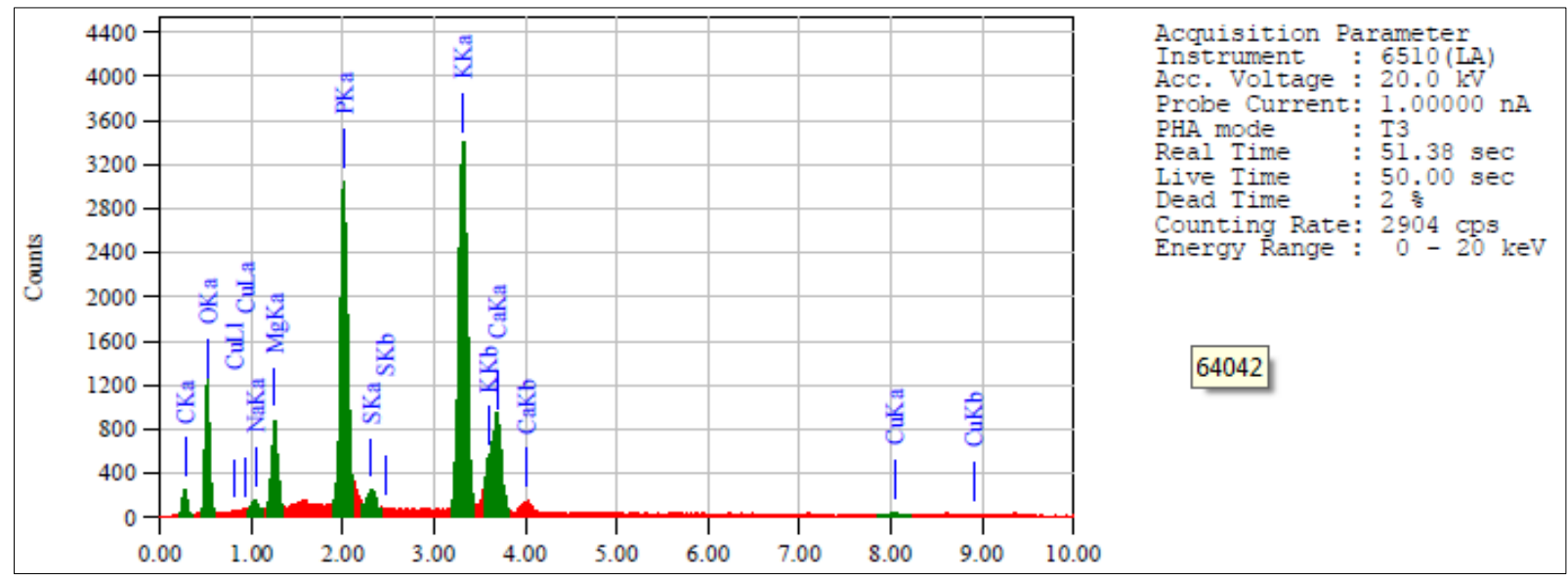

$\mathrm{keV}$

ZAF Method Standardless Quantitative Analysis (Oxide) Eitting Coefficient : 0.0225

Total Oxide : 24.0

Element (keV)

C K

$\begin{array}{ll}\mathrm{Na} & \mathrm{K} \\ \mathrm{Mg} & \mathrm{K}\end{array}$

$\mathrm{E} K$

S K

K K

Ca K

Cu $\mathrm{K}$

0.277

Mas $3 \%$
13.47

Sigma

Mol\% 웅

Compound

Mass

Cation

4.8885

Total

1.041

32.42

.26

$0.58 \mathrm{Na} 2 \mathrm{O}$

0.13

4.12

$2.013 \quad 15.30$

2. 307

1.05

25.16

3.312
3.690

7.01

8.040

0.90

0.31

0.09

0.23

0.15

0.11

$8.09 \mathrm{MgO}$

$11.80 \quad 2205$

$1.57 \quad 503$

$15.36 \mathrm{~K} 2 \mathrm{O}$

$8.36 \mathrm{CaO}$

0.68

100.00

$\mathrm{CuO}$

0.76

0.00

0.7245

35.07

2.63

30.31

9.81

1.13

100.00

0.29
2.01

5.85

0.39

7.62

2.07

0.17

4.7686

26.8076

1.7558

47.4484

12.0521

18.40

\section{Biji Nyamplung}

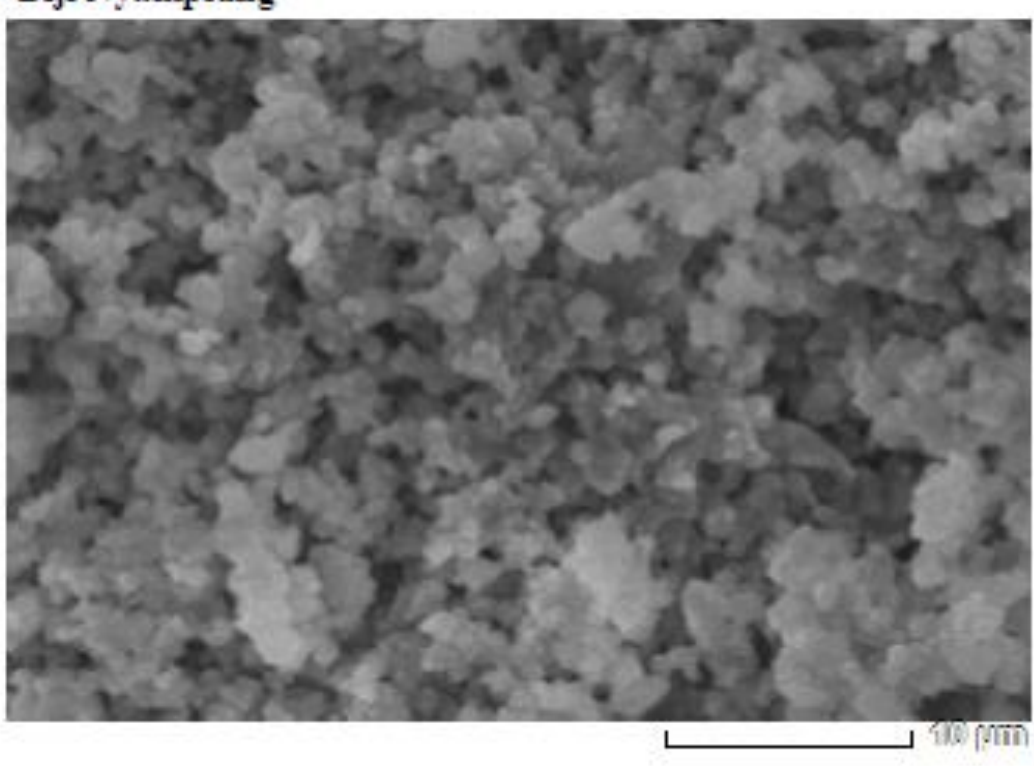

\begin{tabular}{ll} 
Title & TMG1 \\
\hline Instrument & $=6510($ LR) \\
Volt & $: 20: 00 \mathrm{kV}$ \\
Mag. & $=26,000$ \\
Date & $: 2017 / 07 / 21$ \\
Pivel & $: 512 x 364$
\end{tabular}

Gambar 1. Hasil analisis SEM-EDX biji nyamplung dengan perbesaran $3000 \mathrm{x}$ 
Tabel 3. Hasil analisis kandungan biji nyamplung dan indikator kualitas bahan biodisel pada minyak dan biji nyamplung

\begin{tabular}{|c|c|c|c|c|c|}
\hline No & Sampel & Parameter Uji & Nilai & Satuan & Metode \\
\hline 1 & $\begin{array}{l}\text { Biji } \\
\text { nyamplung }\end{array}$ & $\begin{array}{l}\text { Kadar air } \\
\text { Kadar abu } \\
\text { Lemak } \\
\text { Serat kasar } \\
\text { Protein }\end{array}$ & $\begin{array}{c}36,13 \pm 0,5966 \\
1,6505 \pm 0,1286 \\
11,4601 \pm 0,4099 \\
49,2098 \pm 0,3089 \\
0,4650 \pm 0,0028\end{array}$ & $\%$ berat & $\begin{array}{c}\text { SNI } 0129811992 \\
\text { Bradford }\end{array}$ \\
\hline 2 & $\begin{array}{l}\text { Minyak } \\
\text { nyamplung }\end{array}$ & $\begin{array}{l}\text { Angka asam } \\
\text { Nilai kalor } \\
\text { Angka setana }\end{array}$ & $\begin{array}{c}27,98 \\
30.865 \\
36,5\end{array}$ & $\underset{\substack{\mathrm{mg} \mathrm{KOH} / \mathrm{gr} \\
\mathrm{j}}}{ }$ & $\begin{array}{c}\text { FBI-a02-01 } \\
\text { Bomb calorimeter } \\
\text { ASTM D } 613\end{array}$ \\
\hline 3 & $\begin{array}{l}\text { Biodisel } \\
\text { nyamplung }\end{array}$ & $\begin{array}{l}\text { Densitas } \\
\text { Viskositas } \\
\text { Angka setana } \\
\text { Nilai kalor } \\
\text { Bilangan penyabunan } \\
\text { Angka asam } \\
\text { Metil ester }\end{array}$ & $\begin{array}{c}0,8931 \\
0,1572 \pm 0,0054 \\
79,5 \\
41.388 \\
48,13 \\
1,86 \\
26,6941\end{array}$ & $\begin{array}{c}\mathrm{gr} / \mathrm{ml} \\
\mathrm{cm}^{2} / \mathrm{s} \\
- \\
\mathrm{j} / \mathrm{gr} \\
\mathrm{mg} \mathrm{KOH} / \mathrm{gr} \\
\mathrm{mg} \mathrm{KOH} / \mathrm{gr} \\
\%\end{array}$ & $\begin{array}{c}\text { Gravimetri } \\
\text { ASTM D } 613 \\
\text { Bomb calorimeter } \\
\text { FBI-a02-03 } \\
\text { FBI-a02 } 01 \\
\text { GCMS }\end{array}$ \\
\hline
\end{tabular}

Tempat uji : Laboratorium Terpadu Universitas Diponegoro, Semarang (2017)

Tabel 4. Senyawa penyusun biodisel dari biji nyamplung

\begin{tabular}{|c|c|c|c|c|}
\hline No & Sampel & Komponen & $\begin{array}{c}\text { Rumus } \\
\text { kimia }\end{array}$ & $\begin{array}{c}\text { Komposisi } \\
\text { (\%area) }\end{array}$ \\
\hline 1 & $\begin{array}{l}\text { Biodisel } \\
\text { nyamplung }\end{array}$ & $\begin{array}{l}\text { Hexadecanoic acid, methyl ester } \\
\text { 9,12-Octadecadienoic acid (Z,Z)-, methyl ester } \\
\text { 9-Octadecenoic acid (Z)--, methyl ester } \\
\text { Octadecanoic acid, methyl ester } \\
\text { Hexadecanoic acid, 2-hydroxy-1,3- propanediyl ester } \\
\text { 4,8-Ethano-4H-1,3-benzodioxin, hexa } \\
\text { hydro- Bicyclo[5.3.0]decane, 2-methyl ene-5-(1- } \\
\text { methylvinyl)-8-methyl ester } \\
\text { 9-Octadecenoic acid (Z)-, methyl ester } \\
\text { Eicosanoic acid, methyl ester } \\
\text { Methyl eicosa-5,8,11,14,17-pentaenoate } \\
\text { DI-(9-OCTADECENOYL)- } \\
\text { GLYCEROL } \\
\text { Hexadecanoic acid, 2-hydroxy-1- } \\
\text { (hydroxymethyl)ethyl ester } \\
\text { Octadecanoic acid, 2-hydroxy-1,3- propanediyl ester } \\
\text { 1,2Benzenedicarboxylic acid, dioctyl ester } \\
\text { Docosanoic acid, methyl ester } \\
\text { 9,12-Octadecadienoic acid (Z,Z)-, 2,3- } \\
\text { dihydroxypropyl ester } \\
\text { 9-Octadecenoic acid(Z)9-octadecenyl ester } \\
\text { Tetracosanoic acid, methyl ester } \\
\text { 2,6,10,14,18,22-Tetracosahexaene, 2,6,10,15,19,23- } \\
\text { hexamethyl-ester }\end{array}$ & $\begin{array}{c}\mathrm{C} 17 \mathrm{H} 34 \mathrm{O} 2 \\
\mathrm{C} 19 \mathrm{H} 34 \mathrm{O} 2 \\
\mathrm{C} 19 \mathrm{H} 36 \mathrm{O} 2 \\
\mathrm{C} 19 \mathrm{H} 38 \mathrm{O} 2 \\
\mathrm{C} 35 \mathrm{H} 68 \mathrm{O} 5 \\
\\
\mathrm{C} 10 \mathrm{H} 16 \mathrm{O} 2 \\
\mathrm{C} 15 \mathrm{H} 24 \\
\mathrm{C} 19 \mathrm{H} 36 \mathrm{O} 2 \\
\mathrm{C} 21 \mathrm{H} 42 \mathrm{O} 2 \\
\mathrm{C} 21 \mathrm{H} 32 \mathrm{O} 2 \\
\mathrm{C} 39 \mathrm{H} 72 \mathrm{O} 5 \\
\mathrm{C} 19 \mathrm{H} 38 \mathrm{O} 4 \\
\mathrm{C} 39 \mathrm{H} 76 \mathrm{O} 5 \\
\mathrm{C} 24 \mathrm{H} 38 \mathrm{O} 4 \\
\mathrm{C} 23 \mathrm{H} 46 \mathrm{O} 2 \\
\mathrm{C} 21 \mathrm{H} 38 \mathrm{O} 4 \\
\mathrm{C} 36 \mathrm{H} 68 \mathrm{O} 2 \\
\mathrm{C} 25 \mathrm{H} 50 \mathrm{O} 2 \\
\mathrm{C} 30 \mathrm{H} 50\end{array}$ & $\begin{array}{l}0,23 \\
0,21 \\
0,28 \\
0,74 \\
\\
0,29 \\
\\
0,34 \\
\\
0,48 \\
0,36 \\
7,90 \\
0,31 \\
0,24 \\
1,50 \\
0,11 \\
0,21\end{array}$ \\
\hline
\end{tabular}

Tempat uji : Laboratorium Terpadu Universitas Diponegoro, Semarang (2017)

\section{Yield Biodisel dari Minyak Biji Nyamplung}

Yield biodisel yang dihasilkan dari minyak biji nyamplung pada penelitian ini sebesar
$82,87 \%$. Hal tersebut sesuai dengan hasil yield biodisel dari minyak nyamplung melalui transesterifikasi satu tahap 79,03-89,00\% (Muniarsih, 2009) dan sebesar $83-91 \%$. 


\section{Kualitas Produk Biodisel dari Miyak Biji Nyampung}

\section{a. Masa jenis (Densitas)}

Masa jenis atau densitas merupakan salah satu parameter keberhasilan reaksi transesterifikasi. Masa jenis menunjukkan perbandingan berat per satuan volume (Prihandana et al., 2006). Hasil pengukuran produk dari minyak nyamplung ini adalah 0,8931 $\mathrm{gr} / \mathrm{ml}$ atau $893,1 \mathrm{~kg} / \mathrm{m}^{3}$, sehingga meskipun melebihi namun relatif masih memenuhi standar masa jenis SNI sebagai biodisel yaitu antara 850$890 \mathrm{~kg} / \mathrm{m}^{3}$. Masa jenis minyak nabati lebih tinggi dibanding masa jenis biodisel yang ditetapkan SNI. Nilai masa jenis tersebut menunjukkan bahwa proses pemurnian biodisel relatif cukup berhasil. Kurang murninya biodisel karena masih mengandung pengotor, dapat menyebabkan nilai masa jenis tinggi.

\section{b. Viskositas kinematik}

Minyak nabati memiliki viskositas di atas viskositas bahan bakar disel. Hal inilah yang menjadi kendala penggunaan langsung minyak nabati sebagai bahan bakar disel. Salah satu tujuan transesterifikasi adalah menurunkan viskositas minyak nabati agar memenuhi standar bahan bakar diesel. Viskositas biodisel mempengaruhi kecepatan alir bahan bakar melalui injektor sehingga dapat mempengaruhi atomisasi bahan bakar di dalam ruang bakar. Selain itu, viskositas juga berpengaruh secara langsung terhadap kemampuan bahan bakar bercampur dengan udara.

Viskositas kinematik biodisel yang dihasilkan pada penelitian ini adalah 0,1572 \pm $0,0054 \mathrm{~cm}^{2} / \mathrm{s}$ atau $15,7 \mathrm{~mm}^{2} / \mathrm{s}$, sedangkan viskositas kinematik biodisel menurut SNI pada suhu $40{ }^{\circ} \mathrm{C}$ berkisar $2,3-6,0 \mathrm{~mm}^{2} / \mathrm{s}$, sehingga masih terlalu tinggi sebagai bahan bakar mesin disel sesuai dengan ketentuan SNI. Untuk itu masih diperlukan penyempurnaan sintesa biodisel melalui proses transesterifikasi dua tahap, pengalihan jenis dan kadar katalis ataupun perubahan suhu pada prosesnya.

\section{c. Angka Setana}

Angka setana menunjukkan seberapa cepat bahan bakar mesin disel yang diinjeksikan ke ruang bakar dapat terbakar secara spontan (setelah bercampur dengan udara). Semakin tinggi angka setana, semakin cepat bahan bakar mesin disel terbakar setelah diinjeksikan ke dalam ruang bakar (Prihandana et al., 2006). Angka setana yang tinggi juga berhubungan dengan rendahnya polutan NOx (Knothe et al., 2005). Secara umum biodisel memiliki angka setana yang lebih tinggi daripada solar. Panjang rantai hidrokarbon dan tingginya kandungan asam lemak jenuh biodisel menyebabkan tingginya angka setana dibandingkan solar (Knothe et al., 2005).

Angka setana yang semula sebesar 36,5 pada minyak nyamplung dapat ditingkatkan menjadi 79,5 setelah menjadi biodisel. Angka setana tersebut sudah memenuhi SNI yang mempersyaratkan angka setana biodisel minimal adalah 51, sehingga telah memenuhi syarat sebagai bahan bakar mesin disel.

\section{d. Nilai Kalor}

Nilai kalor yang dihasilkan pada minyak nyamplung yang hanya 30.865 joule/gram minyak nyamplung meningkat menjadi sebesar 41.388 joule/gram biodisel nyamplung. Jika pada esterifikasi menggunakan persen berat katalis yang tidak maksimal dalam mengkonversi asam lemak bebas menjadi metil ester maka kalor yang dihasilkan akan semakin kecil karena kadar metil ester yang dihasilkan akan lebih rendah.

\section{e. Titik Kabut}

Temperatur pada saat terjadi kristal pada biodisel yang dapat dilihat dengan mata disebut titik kabut (cloud point). Meski bahan bakar masih bisa mengalir pada titik ini, keberadaan kristal di dalam bahan bakar bisa mempengaruhi kelancaran aliran bahan bakar di dalam filter, pompa, dan injektor. Titik kabut dari biodisel minyak nyamplung pada penelitian ini adalah $20^{\circ} \mathrm{C}$. Titik kabut biodisel minyak nyampug tersebut sedikit melebihi SNI yaitu maksimal $18^{\circ} \mathrm{C}$. Menurut Knothe et al. (2005), pada umumnya titik kabut dan titik tuang biodisel lebih tinggi dibandingkan dengan solar. Tingginya titik kabut ini berhubungan dengan tingginya kandungan asam lemak jenuh dan rendahnya asam lemak tak jenuh penyusun biodisel.

\section{f. Angka asam}

Angka asam menunjukkan adanya asam lemak bebas dalam biodisel. Adanya asam lemak bebas dalam biodisel dapat mengakibatkan terbentuknya abu pada saat pembakaran . Angka asam dapat menjadi indikator kerusakan yang terjadi pada biodisel, yang diduga akibat terjadinya aktivitas oksidasi. Angka asam yang semula sangat besar pada minyak nyamplung yakni sebesar $27,98 \mathrm{mg} \mathrm{KOH/gram} \mathrm{dapat}$ diturunkan secara signifikan menjadi $1,86 \mathrm{mg}$ $\mathrm{KOH} / \mathrm{gram}$ biodisel. Meskipun demikian bilangan asam biodisel tersebut masih terlalu tinggi, dimana SNI mempersyaratkan maksimal hanya $0,8 \mathrm{mg} \mathrm{KOH} / \mathrm{gram}$ biodisel. Munculnya angka asam yang cukup tinggi ini dimungkinkan karena proses transesterifikasi yang agak lama. Hal ini seperti yang telah dilaporkan Sumangat dan Hidayat (2008), bahwa dengan waktu pengendapan yang lebih lama, mengakibatkan 
meningkatnya bilangan asam. Selain itu penyimpanan produk biodisel tanpa ditutup juga mengakibatkan tingginya angka asam karena aktivitas oksidasi.

\section{g. Gliserol total}

Gliserol total merupakan salah satu parameter kualitas yang penting. Tingginya gliserol total dalam produk biodisel, selain kurang sempurnanya proses pemurnian juga menunjukkan kurang sempurnanya proses transesterifikasi. Gliserol total yang tinggi menunjukkan masih banyak minyak yang belum dapat dikonversi menjadi metil ester dari suatu proses transesterifikasi. Tingginya gliserol total juga dapat menunjukkan rendahnya kemurnian biodisel. Gliserol total produk biodisel penelitian ini adalah 0,26\%. Hasil ini masih sedikit di atas dari kadar gliserol maksimal SNI yaitu 0,24 \%.

\section{h. Kadar alkil ester}

Kadar alkil ester dapat menunjukkan kesempurnaan proses transesterifikasi. Kadar alkil ester yang tinggi menunjukkan proses transesterifikasi untuk mengkonversi trigliserida menjadi alkil ester telah berjalan maksimal. Hal tersebut juga menunjukkan kerusakan yang diakibatkan aktivitas oksidasi elkil ester menjadi asam lemak bebas rendah. Kadar alkil ester biodisel dari penelitian ini adalah 99,71\% dan lebih tinggi dibandingkan kadar minimal yang ditetapkan SNI yitu sebesar 96,5\% sehingga telah memenuhi syarat sebagai bahan bakar mesin disel.

\section{Kesimpulan dan Saran}

Pembuatan biodisel dari buah nyamplung (Callophylum inophyllum) dalam penelitian ini menghasilkan kesimpulan sebagai berikut :

1. Yield biodisel yang dihasilkan dari minyak biji nyamplung pada penelitian ini sebesar $82,87 \%$, berada pada kisaran yield biodisel hasil para peneliti terdahulu melalui transesterifikasi satu tahap sebesar 79,03 $91 \%$. Angka setana dan alkil ester pada biodisel yang dihasilkan masing-masing sebesar 79,5 dan 99,71\% sudah memenuhi Standar Nasional Indonesia (SNI). Densitas yang dihasilkan sebesar $893,1 \mathrm{~kg} / \mathrm{m}^{3}$, titik kabut $20^{\circ} \mathrm{C}$ dan gliserol total $0,26 \%$ sudah mendekati SNI dengan selisih yang tidak signifikan, sedangkan angka asam yang dihasilkan sebesar 1,86 mg KOH/gram biodisel dan viskositas biodiselnya $15,7 \mathrm{~mm}^{2} / \mathrm{s}$ belum memenuhi SNI secara signifikan.

2. Untuk menyempurnakan angka asam dan viskositas tersebut masih diperlukan penyempurnaan proses sintesa biodisel melalui diversifikasi jumlah tahapan esterifikasi, alternatif jenis dan kadar katalisator ataupun optimalisasi suhu reaksi transesterifikasinya.

Berdasarkan hasil penelitian ini maka disarankan selain uji coba penanaman pohon nyamplung (Callophylum inophyllum) yang dilanjutkan dengan penanaman masal di wilayah pantai Kabupaten Brebes sebagai lokasi penelitian tahun kedua, sekaligus dilakukan peningkatan kualitas biodisel yang dihasilkan agar semua indikatornya sesuai SNI.

Ucapan terima kasih disampaikan kepada Menteri Riset, Teknologi dan Pendidikan Tinggi c.q Direktur Riset dan Pengabdian kepada Masyarakat yang telah mendanai pelaksanaan penelitian PPT ini.

Gavrilescu, M. and Y. Chisti. 2005. Biotechnologya sustainable alternative for chemical industry. Biotechnology Adv 23(7-8): 471499.

Knothe, G., Van Gerpen, J. H. and Krahl, J. (2005). The biodisel handbook, AOCS Press, Champaign, III.

Leksono, B., R.L. Hendrati, Mahudi, E. Windyarini dan T.M. Hasnah. 2012. Pemuliaan Nyamplung (Calophyllum Inophyllum L.) untuk Bahan Baku Biofuel : Keragaman Produktivitas Biodiesel dan Kandungan Resin Kumarin Dari Populasi Nyamplung Di Indonesia. Insentif Peningkatan Kemampuan Peneliti dan Perekayasa. 
Kerja sama Badan Penelitian Dan Pengembangan, Kementerian Kehutanan dengan Kementerian Riset Dan Teknologi. Jakarta.

Muniarsih, D. (2009). Kajian Proses Produksi Biodisel dari Minyak Biji Nyamplung (Calophyllum inophyllum L.). Skripsi, Fakultas Teknologi Pertanian Institut Pertanian Bogor.

Prabowo, D.A.. 2013. Tanggapan terhadap Artikel Pengembangan Bahan Bakar Nabati Biofuel dari Mikroalga sebagai Pengganti Bahan Bakar Minyak di Indonesia tulisan Nur Fitriana Ariyanti, Fakultas Biologi, Universitas Gadjah Mada, Yogyakarta. Labotarory of Algae, Graduate School of Enginnering and Science, University of the Ryukyus, Okinawa - Japan.

Prihanto, A., B. Pramudono dan H. Santosa. 2013. Peningkatan Yield Biodisel dari Minyak Biji Nyamplung melalui Transesterifikasi Dua Tahap. Momentum, 9 (2) : 46-53.

Prihandana, P., Hendroko, R. dan Munamin, M. (2006). Menghasilkan Biodisel Murah Mengatasi Polusi dan Kelangkaan BBM. Jakarta : PT. Agromedia Pustaka

Sumangat, D. dan Hidayat, T. (2008). Karakteristik Metil Ester Minyak Jarak Pagar Hasil Poses Transesteriikasi satu dan dua Tahap. J.Pascapanen 5: 18-26

Hasibuan, S., Sahirman dan NMA Yudawati. 2013. Karakteristik Fisikokimia Dan Antibakteri Hasil Purifikasi Minyak Biji Nyamplung (Calophyllum Inophyllum L.). Agritech, 33 (3) : $311-319$.

Hidayati, S. 2015. Pra Rancangan Pabrik Biodisel dari Minyak Biji Nyamplung dengan Proses Esterifikasi dan Transesterifikasi kapasitas 15.000 ton/Tahun. Jurusan Teknik Kimia, Fakultas Teknik. Universitas Muhammadiyah Surakarta. Surakarta.

Muhamadi, E. Aminullah dan B.Soesilo. 2001. Analisis Sistem Dinamis Lingkungan Hidup, osial, Ekonomi dan Manajemen.Pusat Studi Kebijakan dan Dinamika Sistem- Penerbit UMJ Press. Jakarta. $415 \mathrm{p}$.

Sukmana,N.C. Dan E.Purwanti. 2011. Kalor Biodiesel Hasil Esterifikasi Dengan Katalis Asam Sitrat Dan Transesterifikasi Dengan
Katalis Kalium Hidroksida Minyak Biji Nyamplung (Calophyllum Inophyllum). Jurusan Kimia, Fakultas Matematika Dan Ilmu Pengetahuan Alam , Institut Teknologi Sepuluh Nopember. Surabaya.

Sutrisyani dan S. Rohani. 2009. Panduan Praktis Analisis Kualitas Air Payau. Pusat Riset Perikanan Budidaya. Departemen Kelautan dan Perikanan. Jakarta.

Suyono, Siswanto dan Gunistiyo. 2012. Kajian Kawasan Konservasi Laut Daerah-Taman Pesisir Pantai Randusanga-Kaliwlingi Kabupaten Brebes. Kerjasama Dinas Kelautan Dan Perikanan Kabupaten Brebes dengan Lembaga Penelitian Universitas Pancasakti Tegal.

Suyono. Study on Carbon Content and Ecological Mangrove Index in Muarareja, Tegal, Cental Java. 2017. ADRI International Journal of Engineering and Natural Science, May 2017, 1 (1) :

Suyono, N.Zuhry dan Gunistiyo. 2014. Strategi Penanganan Kerusakan Mangrove dan Abrasi Pantai Berbasis Geographic Information System dengan Pendekatan Adaptiive Co-Management. Universitas Pancasakti Tegal (Penelitian Hibah Bersaing, dibiayai Dirjen Dikti Departemen Pendidikan dan Kebuadayaan).

Suyono, Supriharyono, B. Hendarto and O. K. Radjasa. 2015. Management Strategies of Mangrove Degradation in Coastal Areas of Brebes Regency, Central Java, Indonesia. International Journal of Coastal Zone Management, member of OMICS Group, USA,

http://dx.doi.org/10.4172/jczm.1000401, 2015, 18 (2) : 1-12.

Suyono, N.U.Hartati dan A.Rizkiani. 2015. Kajian Keberadaan Mangrove terhadap Produksi Udang Alami di Muara Sungai Tanyep Desa Randusanga Kulon Kabupaten Brebes. Fakultas Perikanan Dan IImu Kelautan, Universitas Pancasakti Tegal. Tegal.

Venkanna, B.K. and Venkataramana, R.C. (2009). Biodisel Production and Optimization from Calophyllum Inophyllum Linn Oil (Honne Oil) - A Three Stage Method. Bioresource Technology 100: 5122-5125. 